\title{
Comparison between two different conceptual mathematical models in prediction of direct runoff hydrographs from a small watershed
}

\section{S.N. BANSUDE, G.L. CHUNALE, A.A. SHINDE AND PRAVENDRA KUMAR}

Received : 23.12.2014; Revised : 19.02.2015; Accepted : 03.03.2015

See end of the Paper for authors' affiliation

Correspondence to :

\section{S.N. BANSUDE}

Department of Soil and Water Conservation Engineering, Dr. Panjabrao Deshmukh Krushi Vidyapeeth, AKOLA (M.S.) INDIA

Email : bansude.sushilkumar@ gmail.com
ABSTRACT : In the present study, two mathematical models namely (i) Lag and route model and (ii) Muskingum model which are based on unit-step and transfer functions approach were developed for runoff prediction from Shenda park watershed treating the watershed as lumped, linear and time-invariant system. The hydrological data of the study watershed were collected from zonal station of National Agricultural Research Project, Shenda Park, Kolhapur (M.S.) for the years 2000 to 2008. Out of twelve single storm events, nine storm events were included in the analysis for parameters estimation and remaining three storm events were considered for prediction purposes. The model parameters, viz., lag time and $(\tau)$ and storage co-efficient $(\mathrm{K})$ of Lag and route model were estimated by the methods of cumulants (Singh, 1988) and moments (Nash, 1957) whereas the model parameter storage constant $(\mathrm{K})$ for Muskingum model was estimated by using method suggested by Jawed (1973). Performance evaluation of these two developed model in determining direct runoff hydrograph ordinates were evaluated using various statistical indices such as correlation co-efficient (R), special correlation co-efficient (Rs.), co-efficient of efficiency (CE) and root mean square error (RMSE). The results showed that both the developed model can be used for prediction of the direct run off hydrograph from the study watershed, however, direct runoff hydrographs obtained through Muskingun models are much closer to actual observed direct runoff hydrograph than that of Lag and route model.

- KEY WORDS : Lag and route model, Muskingum model, Unit-step transfer functions

- HOW TO CITE THIS PAPER : Bansude, S.N., Chunale, G.L. Shinde, A.A. and Kumar, Pravendra (2015). Comparison between two different conceptual mathematical models in prediction of direct runoff hydrographs from a small watershed. Internat. J. Agric. Engg., 8(1) : 60-65. 